\title{
EFEK PENGHAMBATAN EKSTRAK DAUN WIDURI (CALOTROPIS SP.) TERHADAP CENDAWAN BUSUK BUAH CABAI (COLLETOTRICHUM CAPSICI)
}

\author{
Puji Sulaksono $^{1}$, Umrah ${ }^{1}$, Ramadhanil' ${ }^{1}$ Parhan K. Lamai' ${ }^{2}$ dan Ramlah Binangkari²
}

\begin{abstract}
Inhibitory effect of widuri (Callotropis sp.) leaf extract on Colletotrichum disease of chilli pepper. Inhibitory effect of widuri (Callotropis sp.) leaf extract (WLE) was determined against radial growth, conidial germination, conidial production on red pepper pod lesions and number of lesions formed on the pod. It was found that, compared with control (no WLE), over $50 \%$ radial growth inhibition was recorded 10 days after WLE application at concentrations of $0.5 \%$ or higher. Inhibitions at similar rate were also found on conidial germination 24 hours after WLE application at concentrations of $8 \%$ or higher. WLE at concentrations of $8 \%$ or higher reduced the number of lesion formation up to at least $50 \% 8$ days after inoculation of the pathogen. At least $50 \%$ reduction in the conidial production was recorded when WLE was applied at concentrations of $4 \%$ or higher.
\end{abstract}

Key words : extract, widuri, Calotropis, Colletotrichum capsici, chilli pepper.

\section{PENDAHULUAN}

Buah cabai dikonsumsi sebagai penyedap makanan. Pada umumnya penduduk di Sulawesi amat menggemari rasa pedas buah cabai sebagai penambah selera makan. Karena itu nilai konsumsi lokal cabai di daerah ini tergolong tinggi sehingga akibatnya buah cabai merupakan komoditas pertanian yang utama di seluruh Sulawesi.

Secara nasional produktifitas buah cabai pada tahun 1992 baru mencapai kurang lebih sepertiga dari potensi produksi per Ha dan salah satu penyebab umum rendahnya produktifitas tersebut ialah kurang efektifnya pengendalian hama dan penyakit (Kasijadi \& Soleh, 1996). Penyakit utama cabai di daerah Palu (Sulawesi Tengah) dan sekitarnya di antaranya ialah penyakit busuk buah cabai (antraknosa) yang disebabkan oleh Colletotrichum capsici (Januarita, 1997). Penyakit ini merupakan penyakit yang penting di Indonesia karena pada menjelang tua menyebabkan kehilangan hasil panen sampai 50 \% (Suryaningsih \& Suhardi, 1993).

Ekstrak daun tanaman widuri (Calotropis sp., Asclepiadaceae) menurut hasil penelitian Syukur \& Syahraeni (1998) dan pengamatan Umrah (komunikasi pribadi) dapat menghambat pertumbuhan cendawan. Penelitian ini bertujuan untuk mengetahui apakah ekstrak daun widuri dapat menekan pertumbuhan dan reproduksi cendawan C. capsici.

\section{Isolasi C. capsici}

Bagian buah cabai yang terinfeksi berikut sedikit bagian yang sehat diambil dan dicelupkan berturut-turut dalam alkohol $70 \%$ selama 30 detik, $\mathrm{NaOCl}$ 0,525\% selama 60 detik dan akuades steril selama beberapa saat. Potongan tersebut ditanam pada medium agar kentang dekstrosa (AKD) yang dekstrosanya diganti dengan gula pasir (sukrosa). Setelah diinkubasi pada suhu ruang selama 6 hari, isolat diidentifikasi dengan membandingkan morfologi konidia dan hifanya dengan morfologi dan hifa Colletotrichum sp. yang terdapat pada referensi. Selanjutnya isolat yang menunjukkan morfologi sebagai Colletotrichum diinokulasi ke buah cabai sehat dan gejala yang timbul dibandingkan dengan gejala yang terdapat pada buah sumber inokulum. Isolat yang memberikan gejala yang sama dengan gejala awal dipandang sebagai C. capsici. Referensi yang digunakan untuk membandingkan morfologi atau gejala serangan adalah Barnett (1969), Semangun (1991), dan Dwidjoseputro (1978).

\section{METODE PENELITIAN}

\footnotetext{
${ }^{1}$ Dosen Jurusan Hama dan Penyakit Tumbuhan, Fakultas Pertanian Universitas Tadulako, Palu.

${ }^{2}$ Alumni Fakultas Pertanian Universitas Tadulako, Palu.
} 


\section{Pembuatan Ekstrak Daun Widuri}

Pembuatan ekstrak pada dasarnya dilakukan dengan mengikuti metode Supriadi (1997). Daun widuri sehat yang mekar sempurna dikeringkan selama 12 jam dalam oven pada suhu $40^{\circ} \mathrm{C}$, lalu diblender sampai halus. Serbuk daun sebanyak $100 \mathrm{~g}$ dimasukkan dalam perkolator yang berisi $500 \mathrm{ml} \mathrm{n-}$ heksan kemudian didiamkan selama 24 jam. Setelah itu kran perkolator dibuka untuk mengeluarkan perkolatnya. Ditambahkan lagi n-heksan sebanyak $300 \mathrm{ml}$ pada residu dan proses di atas diulang tiga kali hingga perkolat yang keluar tidak berwarna lagi.

Residu dikeluarkan dan dikering-anginkan. Setelah kering residu dimasukkan ke dalam perkolator yang telah dilapisi kapas bebas lemak, ditambah dengan metanol $300 \mathrm{ml}$ dan didiamkan selama 24 jam. Perkolat dikeluarkan lalu metanol sebanyak $200 \mathrm{ml}$ ditambahkan lagi ke dalam perkolator dan proses di atas diulang hingga 3 kali. Semua perkolat yang diperolah kemudian disatukan dan pelarutnya diuapkan dengan menggunakan rotary evaporator. Hasil yang diperoleh berupa zat berbentuk pasta berwarna hitam kecoklatan.

\section{Penyiapan dan Aplikasi Larutan Ekstrak Daun Widuri}

Pasta hasil ekstrak dilarutkan dalam larutan Sandovit dalam akuades (1:50 v/v) karena pasta tidak larut dalam akuades saja. Sandovit adalah suatu bahan pembasah dan perata komersial dengan bahan aktif alkilaril poligikol eter. Konsentrasi ekstrak daun widuri yang disiapkan adalah 5;10;20;40;80;160;320 $\%$ yang digunakan sebagai larutan induk.

Larutan ekstrak sebanyak $1 \mathrm{ml}$ dari masingmasing konsentrasi di atas dicampur dengan $9 \mathrm{ml}$ medium (yakni AKD dengan dekstrosa diganti sukrosa) steril yang hangat $\left(50^{\circ} \mathrm{C}\right)$ sehingga didapatkan konsentrasi akhir ekstrak dalam medium adalah 0,$5 ; 1,0 ; 2,0 ; 4,0 ; 8,0 ; 16,0 ; 32,0 \%$. Untuk medium kontrol (tanpa ekstrak) maka hanya akuades atau larutan Sandovit yang ditambahkan ke medium dengan rasio seperti di atas. Jadi ada dua medium kontrol, yakni kontrol akuades dan kontrol Sandovit.

a) Aplikasi pada koloni cendawan. Medium yang mengandung ekstrak dari tiap konsentrasi di atas dimasukkan ke dalam cawan petri (diameter 9 $\mathrm{cm}$ ). Setelah memadat, medium diinokulasi dengan piringan miselium dengan diameter 0,5 $\mathrm{cm}$ yang diambil dari tepi koloni $C$. capsici berumur 7 hari yang telah ditumbuhkan dalam kondisi suhu ruang. Percobaan ditata dalam rancangan acak kelompok dengan pengelompokkan didasarkan pada posisi cawan petri yang diinkubasi relatif terhadap arah datangnya cahaya matahari dari jendela laboratorium. Perlakuan diulang sebanyak 3 kali.

b) Aplikasi pada konidia. Konidia yang dipanen dari koloni murni C. capsici (ditumbuhkan pada medium AKD) berumur 6 hari diatur agar konsentrasinya menjadi 200.000 konidia per ml akuades. Penghitungan konidia dilakukan dalam haemositometer. Suspensi konidia ini sebanyak 0,9 ml dicampur dengan 0,1 ml larutan ekstrak daun widuri dari tiap-tiap konsentrasi induk yang telah disiapkan sehingga dengan cara ini diperoleh campuran konidia dan ekstrak dengan konsentrasi ekstrak dari 0,5 sampai 32,0\%. Setetes campuran ini diteteskan pada gelas obyek dengan memakai pipet tetes. Gelas obyek ditutup dengan gelas penutup dan diinkubasi selama 16 dan 24 jam didalam desikator yang dasarnya telah diisi dengan air. Percobaan diatur dalam rancangan acak kelompok (biakan yang menjadi sumber konidia berbeda antara kelompok satu dengan yang lain) dengan 3 replikasi.

c) Aplikasi pada buah. Buah cabai merah besar (Capsicum annum) yang sehat dicuci dengan akuades steril. Setelah akuades kering, buah dicelupkan ke dalam larutan ekstrak dan widuri dari berbagai konsentrasi akhir yang telah disiapkan. Ke dalam setiap konsentrasi dicelupkan 6 (enam) buah cabai. Larutan ekstrak pada buah lalu dibiarkan mengering dan setelah itu permukaan buah ditetesi dengan suspensi konidia C. capsici (100.000 konidia per ml) yang diperoleh dengan cara yang telah dijelaskan sebelumnya. Setiap buah diberi 10 tetes $( \pm 5 \mu \mathrm{l}$ setiap tetes) di antara pangkal sampai ujung buah. Tetes yang satu dengan yang lain berjarak relatif sama sesuai dengan panjang masing-masing buah. Tangkai buah dibalut dengan kapas yang dibasahi dengan akuades steril. Buah lalu dimasukkan ke dalam semprong lampu minyak yang pada ujungnya juga diberi kapas yang dibasahi akuades steril. Semprong lalu ditutup rapat kedua mulutnya dengan plastik transparan dan diinkubasi pada suhu ruang selama 48 jam. Pengamatan dilakukan tentang efek ekstrak terhadap pembentukan bercak infeksi oleh $C$. capsici, 2,6 dan 10 hari setelah inokulasi. 
Kemudian konsentrasi ekstrak yang dapat memberikan penurunan pembentukan bercak sebesar $\pm 50 \%$ atau lebih diuji lanjut efeknya terhadap pembentukan konidia pada buah yang diperlukan pula seperti diatas [lihat bagian awal dari sub-sub bab (c) ini]. Percobaan pada buah ini melibatkan 2 isolat, yakni isolat dari daerah Banawa dan Biromaru.

\section{HASIL DAN PEMBAHASAN}

\section{Pertumbuhan Koloni dan Perkecambahan Konidia}

Pertumbuhan vegetatif dalam bentuk pertumbuhan radial koloni C. capsici dipengaruhi oleh konsentrasi ekstrak daun widuri. Hal ini dapat dilihat pada hasil pengukuran diameter koloni pada 2,6 dan 10 hari setelah inokulasi (Tabel 1). Diameter koloni pada medium tanpa ekstrak tanpa Sandovit tidak berbeda dari diameter koloni pada medium yang diberi Sandovit saja (kontrol Sandovit). Ini berarti tidak ada pengaruh Sandovit yang berarti dan karenanya data dari perlakuan kontrol Sandovit ini tidak lagi dibuat sebagai pembanding bagi perlakuan lain.

Efek penghambatan ekstrak terhadap pertumbuhan vegetatif tampak juga pada perkecambahan konidia (Tabel 2). Data dari kedua tabel itu memberi petunjuk adanya efek penghambatan yang semakin kuat dengan semakin tingginya konsentrasi ekstrak. Penghambatan

Tabel 1. Efek ekstrak daun widuri terhadap pertumbuhan radial koloni C. capsici pada medium agar

\begin{tabular}{ccccccc}
\hline \multirow{2}{*}{ Konsentrasi } & \multicolumn{5}{c}{ Diameter koloni (cm) } \\
\cline { 2 - 7 } Ekstrak (\%) & \multicolumn{2}{c}{ 2 HSI*) } & \multicolumn{2}{c}{6 HSI $^{*}$ ) } & \multicolumn{2}{c}{10 HSI*) $^{*}$} \\
\cline { 2 - 7 } & Data asli & \% thd kontrol & Data asli & \% thd kontrol & Data asli & \% thd kontrol \\
\cline { 2 - 7 } 0,0 & $2,1 \mathrm{a}$ & 100 & $6,1 \mathrm{a}$ & 100 & $9,0 \mathrm{a}$ & 100 \\
0,5 & $1,5 \mathrm{~b}$ & 70 & $2,8 \mathrm{~b}$ & 45 & $3,0 \mathrm{~b}$ & 35 \\
1,0 & $1,3 \mathrm{bc}$ & 62 & $2,5 \mathrm{bc}$ & 42 & $2,8 \mathrm{bc}$ & 32 \\
2,0 & $1,2 \mathrm{bc}$ & 59 & $2,3 \mathrm{c}$ & 37 & $2,5 \mathrm{c}$ & 28 \\
4,0 & $1,0 \mathrm{c}$ & 49 & $2,0 \mathrm{~cd}$ & 33 & $2,2 \mathrm{~cd}$ & 25 \\
8,0 & $0,8 \mathrm{~cd}$ & 38 & $1,6 \mathrm{~d}$ & 26 & $1,8 \mathrm{~d}$ & 21 \\
16,0 & $0,6 \mathrm{~d}$ & 29 & $1,0 \mathrm{e}$ & 16 & $1,0 \mathrm{e}$ & 11 \\
32,0 & $0,5 \mathrm{~d}$ & 25 & $0,8 \mathrm{e}$ & 12 & $0,9 \mathrm{e}$ & 10 \\
\hline
\end{tabular}

Angka-angka sekolom yang diikuti oleh huruf yang sama tidak berbeda nyata (uji BNJ, $\alpha=0,01$ ).

*) HSI = Hari Setelah Inokulasi.

Tabel 2. Efek ekstrak daun widuri terhadap perkecambahan konidia C. capsici pada gelas obyek.

\begin{tabular}{ccccccc}
\hline \multirow{2}{*}{ Konsentrasi } & \multicolumn{6}{c}{ Perkecambahan konidia (\%) } \\
\cline { 2 - 7 } Ekstrak (\%) & $\mathrm{x}$ & $\mathrm{Y}$ & \% thd kontrol & $\mathrm{x}$ & $\mathrm{y}$ & \% thd kontrol \\
\cline { 2 - 7 } & 48,7 & $44,2 \mathrm{a}$ & 100 & 56,4 & $48,8 \mathrm{a}$ & 100 \\
0,0 & 35,7 & $36,6 \mathrm{~b}$ & 73 & 43,5 & $41,2 \mathrm{~b}$ & 80 \\
1,5 & 32,9 & $34,9 \mathrm{bc}$ & 67 & 39,3 & $38,7 \mathrm{c}$ & 72 \\
2,0 & 29,5 & $32,8 \mathrm{c}$ & 60 & 34,1 & $35,7 \mathrm{~d}$ & 63 \\
4,0 & 24,5 & $29,7 \mathrm{~d}$ & 50 & 27,7 & $31,7 \mathrm{e}$ & 51 \\
8,0 & 17,8 & $25,0 \mathrm{e}$ & 37 & 19,7 & $26,3 \mathrm{f}$ & 36 \\
16,0 & 11,9 & $20,1 \mathrm{f}$ & 24 & 14,8 & $22,4 \mathrm{~g}$ & 27 \\
32,0 & 6,3 & $14,4 \mathrm{~g}$ & 13 & 8,9 & $17,2 \mathrm{~h}$ & 16 \\
\hline
\end{tabular}

Angka-angka yang sekolom yang diikuti oleh huruf yang sama tidak berbeda nyata (uji BNJ, $\alpha=0,01$ ).

*) JSA = jam setelah aplikasi; $\mathrm{x}=$ data $\%$ asli; $\mathrm{y}=$ data \% hasil transformasi melalui arcsin3. 

pertumbuhan vegetatif cendawan baik terhadap pertumbuhan radial maupun terhadap tabung kecambah sebesar $50 \%$ atau lebih tinggi terlihat pada pemberian konsentrasi ekstrak $4 \%$ atau lebih. Penghambatan ini terjadi mungkin karena ekstrak daun widuri mengandung alkaloid (Supriadi, 1997) yang dapat menghambat pertumbuhan C. capsici karena menurut Rice (1992), sebagai alkaloid bersifat anti-cendawan dengan cara kerja mendegradasi dinding sel cendawan.

Data yang diperoleh menunjukkan bahwa perkecambahan konidia yang ada relatif rendah, bahkan demikian juga pada perlakuan tanpa ekstrak (yakni sebesar $56 \%$ setelah 24 jam inkubasi). Penyebab hal ini belum diketahui secara pasti, tetapi Sulaksono dan Pasaru (2000) mendapatkan bahwa pada gelas obyek, konidia cendawan tersebut dapat berkecambah sebanyak 85 \% setelah 48 jam inkubasi.

\section{Efek terhadap Keberhasilan Pembentukan Bercak Oleh C. capsici}

Keberhasilan pembentukan bercak diukur dengan menghitung banyaknya bercak yang terbentuk dibagi dengan banyaknya inokulasi yang dilakukan, yaitu 10 inokulasi per buah. Hasil yang diperoleh ternyata sejalan dengan hasil percobaan pertumbuhan miselium pada medium dan perkecambahan pada gelas obyek. Tabel 3 memperlihatkan bahwa ekstrak daun widuri berpengaruh nyata dalam menurunkan keberhasilan patogen membentuk bercak dan bahwa ekstrak yang konsentrasinya lebih tinggi cenderung lebih menurunkan keberhasilan pembentukan bercak daripada ekstrak yang konsentrasinya lebih rendah. Pemberian ekstrak pada konsentrasi $4 \%$ atau lebih tinggi mengakibatkan penurunan jumlah bercak sebesar $5 \%$ atau lebih dan hasil ini sesuai.

Dengan hasil percobaan pada medium agar dan gelas obyek. Konidia C. capsici yang diinokulasikan pada buah normalnya akan berkecambah, membentuk hife dan kemudian menginfeksi buah. Terjadinya pengurangan bercak yang terbentuk itu mungkin disebabkan oleh terhambatnya perkembangan tabung kecambah dan hife oleh ekstrak sebagaimana didapatkan pada percobaan pertumbuhan koloni dan perkecambahan konidia.

Tabel 3. Pengaruh ekstrak daun widuri terhadap keberhasilan pembentukan bercak oleh C.capsici.

\begin{tabular}{|c|c|c|c|c|c|c|}
\hline \multirow{3}{*}{$\begin{array}{l}\text { Konsentrasi } \\
\text { Ekstrak (\%) }\end{array}$} & \multicolumn{6}{|c|}{ Perkecambahan konidia (\%) } \\
\hline & \multicolumn{3}{|c|}{$\left.4 \times 24 \mathrm{JSI}^{*}\right)$} & \multicolumn{3}{|c|}{$8 \times 24$ JSI } \\
\hline & $\mathrm{x}$ & $\mathrm{Y}$ & $\%$ thd kontrol & $\mathrm{X}$ & $\mathrm{y}$ & $\%$ thd kontrol \\
\hline 0,0 & 41,7 & $40,2 \mathrm{a}$ & 100,0 & 76,7 & $61,2 \mathrm{a}$ & 100,0 \\
\hline 0,5 & 38,3 & $38,2 \mathrm{ab}$ & 92,5 & 71,7 & $57,9 a b$ & 94,0 \\
\hline 1,0 & 31,7 & 34,2 bc & 76,0 & 63,3 & 52,9 bc & 82,5 \\
\hline 2,0 & 28,3 & 32,1 c & 68,5 & 58,3 & 49,8 c & 76,0 \\
\hline 4,0 & 18,3 & $25,2 \mathrm{~d}$ & 45,0 & 35,0 & $36,2 \mathrm{~d}$ & 38,0 \\
\hline 8,0 & 8,3 & 15,5 e & 20,0 & 13,3 & 19,8 e & 17,0 \\
\hline 16,0 & 1,7 & $3,8 \mathrm{f}$ & 4,0 & 5,0 & $9,7 \mathrm{f}$ & 6,5 \\
\hline 32,0 & 0,0 & $0,9 \mathrm{f}$ & 0,0 & 1,7 & $3,8 \mathrm{f}$ & 2,0 \\
\hline
\end{tabular}

Angka-angka sekolom yang diikuti oleh huruf yang sama tidak berbeda nyata (uji Duncan, $\alpha=0,05$ ).

*) JSI = Jam Setelah Inokulasi; $\mathrm{x}=$ data \% asli; $\mathrm{y}=$ data \% hasil transformasi melalui arcsin3.

Keberhasilan C. capsici untuk membentuk bercak tampaknya juga ditentukan oleh asal isolat organisme tersebut. Sekalipun tidak berselisih banyak secara angka namun dalam dua kali waktu pengamatan C. capssici asal Biromaru (Tabel 4). Diduga hal ini karena kedua isolat itu merupakan dua ras fisiologik yang menurut Hawksworth, Sutton \& Ainsworth (1983), dapat berlainan kemampuan fisiologisnya dalam bereaksi terhadap suatu bahan kimia.
Berdasarkan pada data pembentukan bercak, konsentrasi ekstrak yang dapat menurunkan keberhasilan pembentukan bercak sebesar $50 \%$ atau lebih dipandang sebagai konsentrasi yang efektif dan efeknya diuji lebih lanjut dalam pembentukan konidia oleh patogen tersebut. Konsentrasi tersebut ialah 4, 8, dan $16 \%$. Konsentrasi 32 \% tidak diuji lanjut karena efeknya terhadap jumlah bercak tidak berbeda nyata dibanding dengan efek konsentrasi $16 \%$. 
Ekstrak widuri juga mengurangi pembentukan konidia oleh $C$. capsici dan semakin tinggi konsentrasi ekstrak semakin besar pula pengurangan produksi konidia (Tabel 5). Pada konsentrasi ekstrak 4 $\%$ atau lebih pengurangan jumlah konidia mencapai $70 \%$ atau lebih tinggi.

Tabel 4. Efek asal isolat C. capsici terhadap keberhasilan pembentukan bercak

\begin{tabular}{llccc}
\hline \multirow{2}{*}{$\begin{array}{l}\text { Konsentrasi } \\
\text { Ekstrak (\%) }\end{array}$} & \multicolumn{3}{c}{ Keberhasilan pembentukan bercak per buah (\%) } \\
\cline { 2 - 5 } & \multicolumn{2}{c}{$4 \times 24$ JSI$\left.^{*}\right)$} & \multicolumn{3}{c}{$8 \times 24$ JSI } \\
\cline { 2 - 5 } & $\mathrm{x}$ & $\mathrm{Y}$ & $\mathrm{x}$ & $\mathrm{y}$ \\
\hline Banawa & 19,6 & $22,4 \mathrm{~b}$ & 38,3 & $34,6 \mathrm{~b}$ \\
Biromaru & 22,5 & $25,2 \mathrm{a}$ & 42,9 & $38,2 \mathrm{a}$ \\
\hline
\end{tabular}

Angka-angka sekolom yang diikuti oleh huruf yang sama tidak berbeda nyata (uji BNT, $\alpha=0,05$ ).

*) JSI = Jam Setelah Inokulasi; $\mathrm{x}=$ data $\%$ asli; $\mathrm{y}=$ data $\%$ hasil transformasi melalui arcsin3.

Tabel 5. Efek ekstrak daun widuri terhadap pembentukan konidia pada buah cabai

\begin{tabular}{|c|c|c|c|c|}
\hline \multirow{3}{*}{$\begin{array}{c}\text { Konsentrasi ekstrak } \\
\text { (\%) }\end{array}$} & \multicolumn{4}{|c|}{ Banyaknya konidia per ml per buah } \\
\hline & \multicolumn{2}{|c|}{4 x 24 JSI*) } & \multicolumn{2}{|c|}{$8 \times 24$ JSI } \\
\hline & Jumlah & 5 thd kontrol & Jumlah & $\%$ thd kontrol \\
\hline 0,0 & $163.333,3$ a & 100,0 & $278.333,3$ a & 100,0 \\
\hline 4,0 & $55.000,0 \mathrm{~b}$ & 32,5 & 78.333,3 b & 28,5 \\
\hline 8,0 & $43.000,0 \mathrm{bc}$ & 27,5 & $56.666,7$ c & 20,5 \\
\hline 16,0 & $40.000,0 \mathrm{c}$ & 21,5 & $41.666,7 \mathrm{~d}$ & 14,5 \\
\hline
\end{tabular}

Angka-angka sekolom yang diikuti oleh huruf yang sama tidak berbeda nyata (uji BNT, $\alpha=0,05$ ).

*)JSI = Jam Setelah Inokulasi.

Bahan-bahan kimia yang bersifat antisporulan sudah dilaporkan, misalnya difenoconazole terhadap sporulasi Venturia inaequalis (Dahmen \& Staub, 1992). Wilcox (1990) melaporkan bahwa sekalipun beberapa fungisida yang ia uji tidak efektif menghambat penyakit, tetapi bila diaplikasikan pasca inokulasi maka fungisida-fungisida tersebut dapat menghambat produksi konidia oleh patogen yang bersangkutan. Sebaliknya, percobaan ini mendapatkan bahwa ekstrak widuri dapat menurunkan penyakit maupun produksi konidia C. capsici. Sifat antisporulan dari ekstrak widuri itu dapat merupakan sifat yang sangat penting karena antisporulan yang efektif dapat menghambat terjadinya epidemi penyakit (Evans, 1968).

Hasil percobaan memberi pertunjuk bahwa ekstrak widuri mempunyai potensi yang nyata untuk menghambat $C$. capsici, karena baik proses vegetatif maupun reproduktif dari patogen ini direduksi secara nyata oleh pemberian ekstrak konsentrasi $1 \%$ atau lebih. Tanaman yang pernah dilaporkan sebagai sumber zat anti cendawan $C$. capsici termasuk bawang putih (Allium sativum) dengan bahan aktif alkaloid, saponin dan tanin dan tanaman Cestrum diurum (day jasmine, famili Solanaceae) dengan bahan aktif yang belum dilaporkan (Grainge \& Ahmed, 1988). Kedua penulis tersebut juga mendaftar beberapa tanaman lain seperti A. cepa, Aegopodium podagraria, Chenopodium album, dan Acacia catechu sebagai tanaman yang mengandung zat anti terhadap beberapa spesies Colletotrichum yang lain. Hanya penulis itu tidak menjelaskan proses biologis mana yang dihambat pada cendawan dan bahwa tanaman widuri juga mempunyai efek anti cendawan.

Pengaruh asal isolat selain terlihat pada pembentukan bercak juga tampak pada reproduksi konidia. Produksi konidia oleh isolat dari Biromaru secara nyata lebih besar daripada produksi konidia oleh isolat dari Banawa (Tabel 6). Jadi, tampaknya isolat Biromaru merupakan patogen yang kurang sensitif terhadap efek ekstrak widuri daripada isolat Banawa baik dalam aspek vegetatif (infeksi dan kolonisasi pada inang) maupun aspek reproduktif (pembentukan konidia). 
Tabel 6. Efek asal isolat C. capsici terhadap pembentukan konidia pada buah

\begin{tabular}{lcc}
\hline \multirow{2}{*}{ Asal isolat } & \multicolumn{2}{c}{ Banyaknya konidia per ml per buah } \\
\cline { 2 - 3 } & $4 \times 24$ JSI$\left.^{*}\right)$ & $8 \times 24$ JSI \\
\hline Banawa & $70.000,0 \mathrm{a}$ & $109.166,7 \mathrm{a}$ \\
Biromaru & $79.166,7 \mathrm{~b}$ & $118.333,3 \mathrm{~b}$ \\
\hline
\end{tabular}

Angka-angka sekolom yang diikuti oleh huruf yang sama tidak berbeda nyata (uji BNT, $\alpha=0,05$ ).

*)JSI = Jam Setelah Inokulasi.

\section{SIMPULAN}

Ekstrak daun widuri memperlihatkan potensi untuk menghambat pertumbuhan miselium dan tabung kecambah konidia serta mengurangi pembentukan bercak dan produksi konidia pada bercak oleh cendawan C. capsici. Potensi tersebut mulai terlihat pada konsentrasi ekstrak sebesar 1,0 \%.

\section{DAFTAR PUSTAKA}

Barnett, H.L. 1969. Illustrated genera of imperfect fungi $\left(2^{\text {nd }}\right.$ ed., $5^{\text {th }}$. Printing). Burgess Publishing Company, Minneapolis.

Dahmen, H. \& T. Staub. 1992. Protective, curative and eradicant activity of difenoconazole against Venturia ineaqualis, Cercospora arachidicola and Alternaria solani. Plant Disease 76(8): 774 - 777.

Dwijoseputro, D. 1978. Pengantar mikologi. Alumni, Bandung.

Evans, E. 1968. Plant diseases and their chemical control. Blackwell Scientific Publications, Oxford.
Grainge, M. \& S. Ahmed. 1988. Handbook of plant with pest-control properties. John Wiley \& Sons, New York.

Hawksworth D.L., B.C. Sutton \& G.C. Ainsworth. 1983. Ainsworth \& Bisby's dictionary of the fungi $\left(7^{\text {th }}\right.$ ed.). Commonwealth Mycological Institute, Kew, Surrey.

Januarita, M. 1997. Identifikasi cendawan penyebab penyakit pada tanaman cabai (Capsicum annum). Laporan Praktek Umum. Fakultas Pertanian Universitas Tadulako, Palu.

Kasijadi, F. \& M. Soleh. 1996. Rakitan teknologi usaha tani bawang merah dan cabe merah. Risalah Lokakarya di Balitkabi 8-9 Mei Malang. Edisi Khusus Balitkabi No. 8, pp 219-230.

Semangun, H. 1991. Penyakit-penyakit tanaman hortikultura di Indonesia. Gajah Mada University Press, Yogyakarta.

Supriadi. 1997. Isolasi alkaloid daun widuri. Laporan Penelitian. Fakultas Keguruan dan Ilmu Pendidikan, Universitas Tadulako, Palu.

Suryaningsih, E \& Suhardi. 1993. Pengaruh penggunaan fungisida untuk mengendalikan penyakit antraknose (Colletotrichum gloeosporoides) pada cabai. Buletin Penelitian Hortikultura 25 (1) : 37-43.

Syukur, A. \& K. Syahreni. 1998. Studi awal penggunaan ekstrak widuri sebagai fungisida botani. Laporan Penelitian, Fakultas Pertanian Universitas Tadulako, Palu.

Wilcox, W.F. 1990. Post infection and antisporulant activities of selected fungicides in control of blossom bligh of sour cherry caused by Monilia fructicola. Plant Disease 74 (10): 808-811. 
Puji Sulaksono, dkk.: Efek penghambatan ekstrak daun widuri terhadap cendawan busuk buah cabai 